\title{
Recombinant Attenuated Salmonella typhimurium Expressing IL-2
}

National Cancer Institute

\section{Source}

National Cancer Institute. Recombinant Attenuated Salmonella typhimurium Expressing

IL-2. NCI Thesaurus. Code C91096.

An orally available, genetically engineered Salmonella typhimurium strain expressing a truncated form of the human cytokine interleukin-2 (IL-2) gene, with antitumor activity. Upon administration of recombinant attenuated S. typhimurium expressing IL-2 (SalpIL2), this Salmonella strain may selectively accumulate and divide in a variety of tumor types, and express IL-2. In turn, IL-2 may induce natural killer (NK) cell proliferation thereby enhancing their activity. This may inhibit the growth of tumor cells. 